\title{
The UAE's Disruptive Policy in Libya
}

\author{
ALI BAKIR \\ Qatar University, Qatar \\ ORCID No: 0000-0003-3098-5771
}

ABSTRACT In the last decade, the United Arab Emirates (UAE) has emerged as a leading counter-revolutionary force in the Middle East. Feeling the heat of change in the region, the small, oil-rich Gulf country adopted an aggressive foreign policy that defined the UAE as a disruptive force that aims to reverse the fledgling democratic trend in the Middle East. After succeeding in Egypt in 2013, Abu Dhabi decided to support field marshal and warlord Khalifa Haftar in Libya to overthrow the UN-recognized government in Tripoli, take over power, and control Libya by force. To that end, the UAE offered massive military, financial, and diplomatic support to Haftar. In this context, the present paper aims to discuss the UAE's interventions in Libya in terms of their nature, extent, motives, goals and repercussions. It highlights the UAE's efforts to weave regional and international alliances to support Haftar and tries to answer the questions why Abu Dhabi has been able to act with impunity in Libya despite being the top foreign player fueling the war there for many years, and whether it will be able to achieve its goals and continue its interventions in the oil-rich North African country or not.

Keywords: UAE Foreign Policy, UAE-Haftar Ties, France, Egypt, Mercenaries, Russia, Political Islam, Arab Spring 


\title{
Introduction
}

\begin{abstract}
A t the end of 2010 and the beginning of 2011, a series of pro-democracy uprisings erupted in several Arab countries, including Tunisia, Egypt, Syria, Yemen, Oman, Bahrain, Libya, and Morocco. Within less than two months, the protests succeeded in toppling the authoritarian regimes in Tunisia and Egypt. At this stage, a domino effect in the Arab world seemed imminent. While some governments were convinced that their home fronts were sufficiently strong and immune, others considered the uprisings a serious threat. The popular revolutions brought political Islam to power and sparked a state of panic among the autocratic and repressive Arab regimes. In the Gulf, the United Arab Emirates (UAE) emerged as the leader of the counter-revolutionary efforts in the Arab world.
\end{abstract}

On June 3, 2013, the UAE and Saudi Arabia backed a military coup in Cairo that toppled Egypt's first democratically elected president in the country's history, Mohammad Morsi, who later died in prison. The coup leader, then Egypt's Minister of Defense General Abdul-Fattah el-Sisi took power, and a trilateral anti-revolution camp emerged. The success of the coup in Egypt gave the counter-revolutionary axis led by the UAE a major regional boost. Abu Dhabi built its case on the narrative that political Islam is a threat and that there is an urgent need to prevent Islamists from ruling or taking power. This message found resonance in some countries in the region and beyond.

Equipped with this narrative, its financial power and its ability to promote itself as a useful client state for certain international powers that might share its goals, the UAE pushed for an aggressive and hostile anti-revolutionary agenda. By focusing on political Islam as a threat and promoting Islamism as a boogeyman, Abu Dhabi managed to distract attention away from the real threat it fears: democracy. This underlying agenda explains why the UAE has supported military coups and favored authoritarian autocracy in the region.

This does not mean that Abu Dhabi was not anti-political Islam, but rather that exaggerating the value of this factor as an explanatory factor of the UAE's foreign policy was meant to shift attention and arguments away from the police nature of the state in UAE, which emerged after 2011 and Abu Dhabi's anti-democracy effort in the region. Another factor that can help explain the UAE's anti-revolutionary agenda is the personal character of the de facto ruler of the UAE since 2014 -namely Muhammed bin Zayid (MBZ) - and his behavior, traits and ambitions. Bruce Riedel, a former official in the Central Intelligence Agency (CIA) who had extensive relations with several high-level Gulf officials, especially in Saudi Arabia, describes MBZ in these terms: "He thinks he is Machiavelli but he acts more like Mussolini." 
As a result, since 2014, Abu Dhabi's interference and involvement in many regional countries has reached an all-time high. The UAE has occupied Yemen, supported the secession of southern Yemen, Northern Iraq and Somalia, imposed a blockade against Qatar, reportedly plotted and/or backed coups in countries including Oman, Turkey, Qatar, Sudan, Tunisia, and Libya and spied on many leaders in ing mercenaries to kill political figures in other countries ${ }^{2}$ and fight its proxy wars, ${ }^{3}$ money laundering and terrorism financing. ${ }^{4}$

Consequently, Abu Dhabi's policy orientation toward Libya in the post-Qaddafi era, and its interference in the oil-rich North African country is not an exception or an isolated case, but rather part of a comprehensive, holistic approach that is mostly related to the nature of the governance in the UAE and MBZ's personal character, the regional ambitions of Emirati foreign policy and the Arab revolutions. These three factors can help us better understand Abu Dhabi's involvement in Libya, as they shape, to a great extent, the UAE as a disruptive regional force.

In 2011, when the Libyan people revolted against Qaddafi, the dictator reacted fiercely and his army responded with deadly force. NATO intervened, Qaddafi was ousted and the country entered into turmoil. On December 17, 2015, an UN-led initiative resulted in a political agreement between the conflicting Libyan parties in Morocco. This agreement, which became known as the al-Skhirat agreement, created a Presidential Council and a High Council of State, and established the Government of National Accord (GNA). The United Nations Security Council (UNSC) unanimously endorsed the agreement and recognized the GNA as the sole, legitimate, executive authority in Libya.

The Tobruk Parliament later established a rival government to the GNA and supported warlord and former army officer Khalifa Haftar. The situation resulted in splitting the Libyan forces between the GNA's forces and Haftar's selfstyled Libyan National Army (LNA). Despite being internationally recognized as Libya's sole legitimate government -to this day- the UAE chose to support Haftar in his quest to control Libya and overthrow the UN-recognized GNA in the capital Tripoli by military force.

This paper discusses the intervention of the UAE in Libya in terms of its na- 
However, in reality, Haftar's army was nothing but a hodge-podge of local, regional, and international mercenaries, tribes, former regime militias, criminal gangs, and even radical Madkhali Salafi groups ture, extent, motives, goals, and repercussions. It explores the ties between the UAE and General Khalifa Haftar, and describes how Abu Dhabi has mobilized all its resources and forged a network of regional and international alliances to support Haftar's military coup, disrupt the political process and ruin the opportunities for a peaceful solution and democratic transition in the country.

\section{The UAE-Haftar Ties}

Starting in 2014, the UAE emerged as the top political and military supporter for Libyan warlord Khalifa Haftar and his self-styled forces, the LNA. The UAE's support was crucial in terms of enabling Haftar's army to expand its territorial reach and control over strategic assets in the Eastern part of the country, such as oil fields, ports, military bases, etc., and sustain his military campaign against Tripoli. Throughout the war in Libya, Abu Dhabi's long and dedicated support for Haftar has taken many forms. The Emiratis literally bought the Libyan warlord an army. They recruited mercenaries on his behalf, ${ }^{5}$ paid for Russian Wagner mercenaries to defend him $^{6}$ and commissioned ${ }^{7}$ multi-na- $^{-}$ tional private military contractors to execute black operations to support him. ${ }^{8}$ Additionally, the UAE secured Haftar aerial superiority over GNA forces by buying his army attack helicopters, offensive drones and even Russian-made fighter jets (at least six MiG-29s and two Sukhoi 24s). ${ }^{9}$ The shopping list also included advanced military equipment, such as the Russian-made air defense system Pantsir; armored personnel carriers (including Panther T6 and Tygra models, both made by companies based in the UAE); ${ }^{10}$ armored vehicles; American, ${ }^{11}$ French, ${ }^{12}$ and Chinese weapons, ${ }^{13}$ including missiles; MANPADS; anti-tanks and other types of sophisticated weapons.

The Emirati support aimed to guarantee the LNA the upper hand over its opponents, mainly the UN-recognized government's forces, and promote Haftar's army as a professional, well-trained, and well-equipped army that deserves to control Libya in order to achieve stability and security. To secure international support and gain legitimacy for its actions, Haftar began fighting against 'Islamist and/or Islamist leaning groups' as an attractive cause for Western powers and audiences.

However, in reality, Haftar's army was nothing but a hodge-podge of local, regional, and international mercenaries, tribes, former regime militias, crim- 


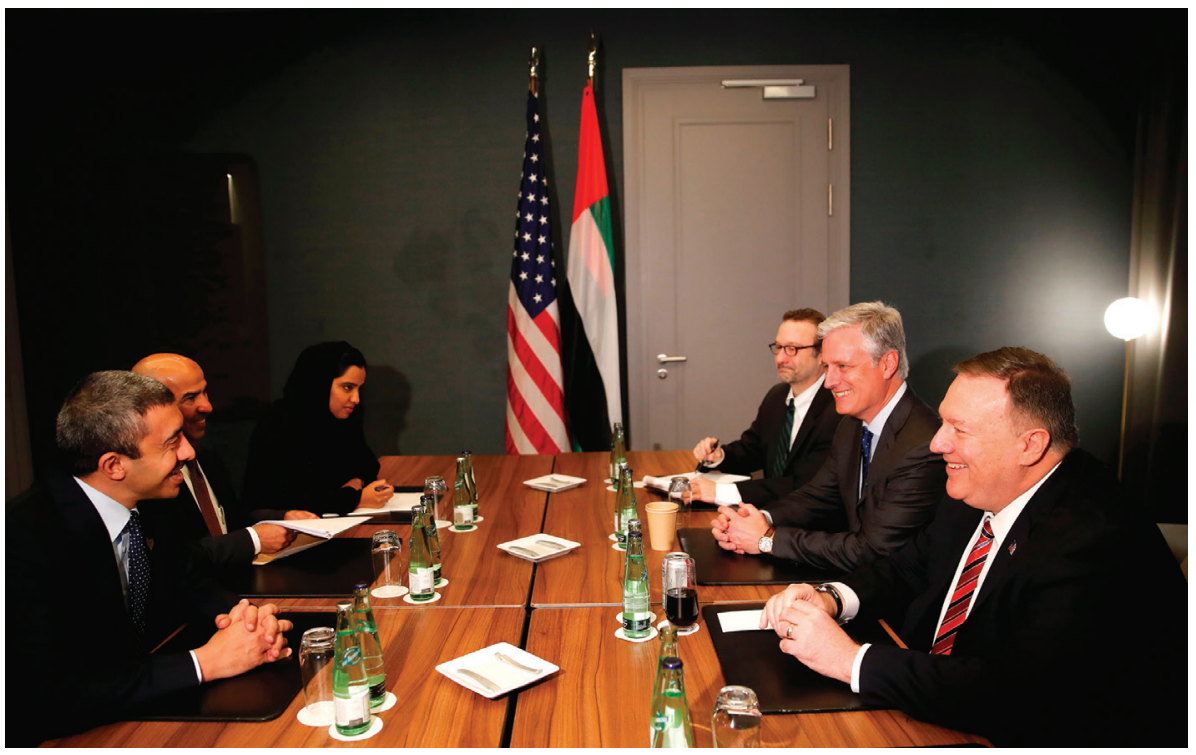

U.S. Secretary of State Mike Pompeo (R) meets UAE Foreign Minister Sheikh Abdullah bin Zayed al Nahyan (L) for bilateral talks prior to the Peace summit on Libya in Berlin, January 19, 2020.

inal gangs, and even radical Madkhali Salafi groups. ${ }^{14}$ The fact that the LNA depends on radical Salafi refutes the claim that Haftar and his backers -mainly the UAE, Egypt, and France- are countering terrorism or radicalism in Libya, and instead reinforces the claim that this card has been used as a pretext to expand the LNA's control over Libya, gain legitimacy and rally support from the international community.

Several facts can back this statement. In 2016, and while the GNA's forces with the support of the U.S., Britain, and Italy were launching a military operation against the last stand of ISIS presence in Sirte, Haftar's army seized the moment not to join forces, but rather to consolidate his power in the eastern part of the country by attacking ports and oil fields and seizing control of more lands. ${ }^{15}$ In fact, ISIS presence in Sirte helped Haftar's forces significantly by keeping Tripoli's forces at bay while he cemented his position in East Libya. This is one main reason why Haftar and his allies such as France, the UAE, and Egypt never attacked ISIS in Sirte.

Besides buying an army for Haftar, the UAE had its own troops, advisers, trainers, bases and military equipment in Libya. In 2016, satellite imagery released by UK-based defense and security intelligence and analysis HIS-Janes revealed that the UAE had set up a military base at al-Khadim airport, $70 \mathrm{~km}$ to the south of al-Marj, the town where Khalifa Haftar's so-called military command is located. According to the information uncovered at the time, Abu Dhabi continued to develop the infrastructure of the military base between June 
2016 and November 2017. Different types of aircrafts stationed at the base were identified via satellite images, ${ }^{16}$ and a UN report later confirmed these details. ${ }^{17}$ Based on open-source intelligence, the UAE has stationed Mirage jets at Egypt's Sidi Barrani base ${ }^{18}$ near the Libyan border and sought to open a new military base in Niger close to the Libyan border. ${ }^{19}$

In 2018, the UAE deployed its own, China-made offensive Wing Loong II drones in Libya. However, due to poor performance and incompetence, the UAE's air superiority was not properly translated into effective gains on the ground. Instead, the UAE ended up being responsible for committing massacres and mass crimes among civilians upon targeting hospitals, mosques, houses, schools and even migrant camps. ${ }^{20}$ International investigations of mass-casualty bombings against civilian areas in July and November 2019 concluded that fighter jets were responsible for the incidents -most likely Mirage 2000-9 aircraft operating out of the UAE- military base in al-Khadim. ${ }^{21}$ Likewise, an investigation on the airstrike that killed 26 unarmed cadets at a military academy in Libya's capital in January 2020 uncovered evidence linking the UAE to this incident; according to the $B B C$ news network, it was caused by a Chinese Blue Arrow 7 missile fired by a Wing Loong II operating from al-Khadim airbase. ${ }^{22}$

\section{UAE's Motives for Supporting Haftar}

The UAE's strategic, anti-democracy orientation is one of the main reasons why Abu Dhabi is the leading anti-revolutionary power in the region. The overwhelming majority of analysts tend to explain and rationalize the UAE's foreign policy behavior through the lens of a perceived enmity with the Muslim Brotherhood (MB) or political Islam in general. However, the fact that the UAE chooses to support military coups, install military dictatorships in many regional countries and even work with and/or support radical armed Islamists such as the Madkhali Salafists in Libya when its agenda requires, is conclusive evidence that its aim is not particularly to oppose the MB but rather the peaceful transition of power on a democratic basis. The UAE's logic behind supporting Haftar in Libya is no different. Aiding a warlord and military dictator is fully consistent with the strategic orientations of the UAE as an anti-democratic power and a disruptive regional force.

Second, by choosing to aid Haftar, the UAE has opted to clone its Egyptian model; its support for a military coup lead by General el-Sisi in 2013 resulted in the overthrow of the first democratically elected president in the history of Egypt and the elimination of the fledgling democracy in that country. Since then, Cairo has been reduced to a mere subordinate for Abu Dhabi and its regional agenda. Even when the interests of the two states differ, the Egyptian 
regime feels the need to make concessions to keep the UAE's financial support flowing, which in turn enables Abu Dhabi to maintain its influence over Egypt. Likewise, from Abu Dhabi's perspective, the warlord Haftar meets all the necessary qualifications to be its man in Libya and serve its interests. A proUAE, oil-rich Libya could elevate the heavy burden of Cairo off Abu Dhabi's shoulders, save billions of dollars that could be channeled into the UAE's regional agenda and certainly open new business opportunities for the Emiratis.

\section{A Haftar-controlled Libya could be used as a launchpad for the UAE's economic and military activities in the region}

Third, and in connection with the aforementioned point, an oil-rich Libya with its strategic geographic position, long coast and several ports on the Mediterranean controlled by a military dictator who is allied with the anti-revolution UAE-led block (Saudi Arabia and Egypt) would have a transformational effect on the North Africa region and beyond -especially on Tunisia, Algeria, and Sudan. This outcome would offer new opportunities for the UAE in North Africa and the Eastern Mediterranean and boost its regional agenda in an unprecedented way, especially vis-à-vis its perceived regional rivals such as Qatar and Turkey.

Fourth, when it comes to hardcore economic and military interests, a Haftar-controlled Libya would offer Abu Dhabi a chance to expand its economic and military footprint in the country and in the region more broadly. It would offer strategic political, economic, and military depth to the small Gulf country in Africa, a foothold where it can robustly operate militarily and economically via military bases installed in Libya and the country's ports on the Mediterranean. A Haftar-controlled Libya could be used as a launchpad for the UAE's economic and military activities in the region.

In this sense, Libya is an invaluable theatre -one the Emiratis can't afford to lose. It is noteworthy that despite being the top foreign player fueling the war in Libya for many years, responsible for a high number of causalities among civilians in the country and the financer of Moscow's military presence in Europe's backyard, Abu Dhabi has enjoyed full impunity. The permanent members of the UNSC, the great powers and even several international organizations have either turned a blind eye on Abu Dhabi's destructive war-business in the region or become complicit. The fact that this is the case not only in Libya, but also in Yemen, Sudan, the Gulf, Somalia, and elsewhere in the region raises questions as to why the UAE enjoys full impunity.

One answer might be related to three particular factors among others. First, the UAE's financial power, which buys it an influence with the leading world 
Egypt's role and influence in the region have been massively downsized since it became incorporated as a follower in the UAE-Saudi regional agenda

powers such as the U.S., France, the UK, Russia, and China. Second, as a top global importer of weapons, the mega arms deals of Abu Dhabi with these countries secure its powerful relations with one of the strongest and most influential lobbies in the world: the arms industry. Third, the UAE's tendency to act as a client state that is willing to execute the dirty job of the big players or black ops on their behalf. In other words, Abu Dhabi's role in Libya and the region is designed to serve the interests of certain great powers along with its own. Thus, Abu Dhabi aims not only to shield itself against any possible punishment but also to guarantee that it will never be held accountable. The fact that the UAE was able to work with France, Russia and the U.S. in Libya is a prime example of how it operates. The UAE's military investment in Haftar and his army went parallel with its effort to promote him as Libya's strongman and secure him wide regional and international support. Abu Dhabi has worked to get Saudi Arabia, Egypt, France, Russia, and the U.S. on board with its plan for Libya.

\section{Bringing in Saudi Arabia and Egypt}

Although less visible than that of the UAE, Egypt, France, Russia, and Saudi support for Haftar has focused mainly on the diplomatic and financial fronts. According to American ${ }^{23}$ and French ${ }^{24}$ sources, Saudi Arabia has provided tens of millions of dollars in financial assistance to aid the LNA offensive against Tripoli, buy the loyalty of tribal leaders, pay militia fighters and recruit members of the Wagner Group, a Russian paramilitary organization that employs mercenaries, to support Haftar's forces. Saudi officials, diplomatic corps and media $^{25}$ have lent Haftar support by trying to delegitimize his local opponents and their backers, especially Turkey. ${ }^{26}$

The less active role of Saudi Arabia in Libya compared to that of the UAE is believed to be an outcome of three main factors. First, MBZ's influence over Mohammed bin Salman (MBS), which resulted in reducing Saudi Arabia to a subordinate ally. Second, Riyadh's catastrophic military campaign in Yemen, which has led the kingdom to get bogged down there. Third, financial constraints in Saudi Arabia due to falling oil prices and increasing economic challenges. ${ }^{27}$

As for Egypt, although typically a leading Arab country and a neighbor of Libya with direct interests in it, its role appears to be secondary compared to the UAE's. Egypt's role and influence in the region have been massively down- 
sized since it became incorporated as a follower in the UAE-Saudi regional agenda. Cairo now has almost no say in all the critical issues in the region, whether it is Syria, Yemen, the Gulf crisis, Palestine, Iraq, or Lebanon. ${ }^{28}$

One interesting note, however, is Egypt's arms shopping list during the period 2014-2018, which entitled it to become the third-largest importer of arms in the world despite its economic hardships. ${ }^{29}$ The UAE sponsored Egypt's arms deals to prop up el-Sisi's regime, buy influence in Western capitals, especially France and Russia, and ensure that those capitals and the Egyptian army return the favor when needed. ${ }^{30}$

In Libya, Cairo's support for Haftar was important given the geographical proximity of Egypt to Libya and the ideological alignment between Haftar and el-Sisi. Egypt put its diplomatic weight behind Haftar. Militarily, Cairo channeled the weapons - usually bought by the UAE- to Haftar via land and air. Just like Abu Dhabi, the idea of a democratic, stable and prosperous Libya is very scary to the Egyptian regime. Dealing with a military regime in Libya would be much easier and more profitable. Cairo reportedly differed with Abu Dhabi in 2019 over Haftar's offensive against Tripoli and the best way to empower him, but had to fall in line after all given two things: First, Abu Dhabi's huge influence on the Egyptian regime and el-Sisi, who owes his position to the UAE's support to his military coup back in 2013. Second, the fact that the UAE is Haftar's primary financial and military supporter.

The Emirati plan, however, eventually backfired and ended up empowering Turkey and Russia in Libya and reducing Egypt's role to that of a mere observer. ${ }^{31}$ This had become clear by the end of 2019 and the beginning of 2020 when Haftar failed to capture Tripoli and his forces fell back, despite the huge support he was receiving. The Emiratis started to become more vocal about their desire to send the Egyptian army to Libya. Figures close to MBZ threatened that if Haftar failed in his mission, the Egyptian army would achieve that mission on his behalf. ${ }^{32}$ The Emiratis even clearly instigated Cairo to engage in a military confrontation against Turkey in Libya, ${ }^{33}$ but Cairo had its own limitations in this regard. ${ }^{34}$

When the GNA defeated Haftar's forces in the second quarter of 2020 at the gates of Tripoli and in the Western part of the country with Turkey's support, the LNA forces collapsed quickly, retreated to Sirte and Jufra, and started to fortify this line to prevent the fall of the Eastern part of Libya. Russia's fighter jets and mercenaries played a crucial role in blocking the progress of GNA forces beyond this line. This is when Cairo saw an opportunity to come back to the game without the need to pay costs; it jumped in to announce an initiative and declare the Sirte-Jufra line a red line for Egypt that should never be crossed. 
An Infographic summarizing the

fortune spent in Libya by the UAE since 2014,

in support of

Khalifa Haftar's

illegitimate armed militia.

21.05.2020 / AA

\section{Spending fortune to weaponize Haftar, UAE could not achieve its ulterior motives in Libya}

United Arab Emirates, which has been supporting Khalifa Haftar's illegitimate armed militia in Libya since 2014, has been spending a fortune for the war despite failures of Haftar

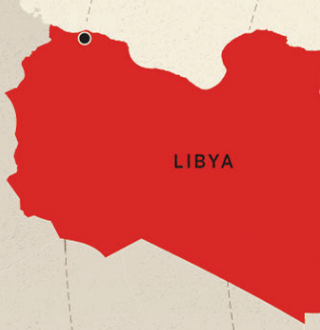

WEAPONS AND OTHER EXPENSES IN LIBYA COVERED BY UAE

(AVERAGE UNIT PRICE, DOLLAR)

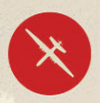

AIRCRAFT

\$25 Million Million UAE-made Yabhon armed drones \$2 Million China-made Wing Loong II armed drones $\$ 100,000$ Russia-made Orlan-10 armed drones $\$ 15$ Million Super Puma helikopterler

\$23 Million French Mirage 2000-9 fighter jets

- Antonov An-26 and Ilyushin IL-76 cargo aircraft

- Belarus-made attack helicopters

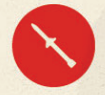

AMMUNITION

- China-made Blue Arrow BA-7 missiles

- China-made GP6 rockets

- US-made MIM-23 Hawk missiles
Based on data collected from air radar systems, UAE sent hundreds of aircraft carrying weapons between Jan. 12 to Feb. 26

UAE also pays salaries of a large number of foreign

mercenaries who have long fought for Haftar
DEFENSE SYSTEMS AND MILITARY VEHICLES

\$14.7 Million Million Russia-made Pantsi S-1 air defense system

$\$ \mathbf{\$ 1 4 5 , 0 0 0}$ UAE-made Nimr, Panthera, Spartan and Tygra type armored personnel carrier

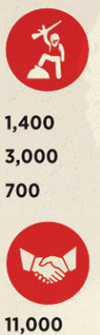

UAE-PAID FOREIGN MERCENARIES

Russian mercenaries

Sudanese mercenaries

Chadian mercenaries

OTHER

tons of jet fuel

Fixing and using military bases

By drawing this red line in Sirte and Jufra, el-Sisi was actually banking on the Russian role in the hope that he could score free gains out of Moscow, which was stalling the progress of the GNA forces. El-Sisi calculated that if the GNA forces decided to stop, he could claim that his threat of military intervention was the reason behind it and boost his image as a power-player in the Libyan file without actually risking anything. 


\section{The UAE-France Alignment}

The idea of a strongman ruling in Libya found resonance in Paris. As a UN Security Council member and one of the world's great powers, France's support for Haftar was critical. While France under President Emmanuel Macron has publicly denied taking sides in the conflict, Paris has aided the Libyan warlord both diplomatically and militarily, providing him and his forces with the political legitimacy, weapons, training, intelligence, and special forces assistance to overthrow the UN-recognized government in Tripoli and rule Libya at least since 2015. The UAE-France connection is important in this regard. Although French support for the authoritarian Haftar appears to conflict with its liberal-democratic values, it is broadly in line with Paris's efforts to develop alliances with authoritarian regimes in the third world in general and the Arab region in particular -including the UAE, Saudi Arabia, and Egypt.

In addition to France's own motives, its alignment with the UAE, Saudi Arabia and Egypt prompted it to play the role of a foreign policy subcontractor for these countries. France ranks third in terms of exporting arms to the Middle East, ${ }^{35}$ and during the last five years, the UAE, Saudi Arabia and Egypt have emerged as top buyers of the French weapons. Further, France and these countries share anti-Islamic and anti-Turkish tendencies. ${ }^{36}$ Abu Dhabi's focus on these elements in its relations with Paris have secured a more proactive and pro-Haftar French role in Libya. Under the pretext of fighting terrorism and radicals, Paris expanded its secret military presence in Libya and increased its support for Haftar at least since 2015. Then Minister of Defense Le Drian saw Haftar as capable of cracking down on Islamists and securing French interests in the country. ${ }^{37}$

Despite Paris's consistent denial of involvement in aiding Haftar, several incidents and leaks exposed the depth of the French support, ${ }^{38}$ including the death of three undercover French special forces soldiers in a helicopter crash in Libya in 2016, ${ }^{39}$ the arrest of 13 armed personnel with French diplomatic passports on the Tunisians borders in $2019^{40}$ and the seizure of French arms in one of Haftar's bases during the same year. ${ }^{41}$ Moreover, at the end of 2019, Haftar issued an official video statement in which he expressed his ultimate gratitude for France as one the first countries to aid him, especially in terms of intelligence and special forces. ${ }^{42}$ In 2020, France used the European naval Force Mediterranean Operation (IRINI) to enforce an arms embargo against the UN-recognized government, the GNA, while turning a blind eye on Haftar's forces, which continued to receive weapons and military equipment from the UAE 
Moscow was happy to fill the vacuum left by the United States and its allies, to make common cause with Egypt and the Emirates, and to secure its own interests via air and land. The GNA accused the mission of being "unbalanced, unfair and biased." ${ }^{43}$

On the diplomatic level, the French support for Haftar was probably even more important. Because of President Macron's appetite for disruptive foreign policy, ${ }^{44}$ the French political role shielded the UAE and encouraged it to continue aiding Haftar. In April 2019, France blocked a European Union statement calling on the renegade military commander to halt his assault on the capital, ${ }^{45}$ prompting GNA Prime Minister Fayez al-Sarraj in April to accuse the Macron Administration of backing a "dictator." 46 Macron's effort to undermine the unity of the European Union (EU) and NATO served Abu Dhabi's goals in Libya very well.

After the pro-Haftar French position was widely uncovered, Paris shifted to a new tactic that depends mainly on disguising the French role under the pretext of fighting terrorism rather than denying supporting Haftar. In an interview with France's then Foreign Minister Le Drian in May 2019, one month after Haftar's military campaign to overthrow the GNA, Le Drian implicitly endorsed Haftar and promoted him as a fighter against terrorism. When asked whether supporting Haftar was a bad idea or not, he didn't say it was bad. He even boasted that Haftar always spoke to him of his desire to serve with civilian authority once elections were held. ${ }^{47}$ In an official hearing for Le Drian in July 2020, he acknowledged supporting Haftar's forces but claimed that "we offer advice and political support for the LNA as it is internationally recognized for its fight against ISIS." 48

\section{Utilizing Russia and the U.S.}

Russian involvement in Libya began in 2015 when Moscow saw an opportunity to exploit the division in the country to secure its economic interests and expand its military footprint in the Middle East. Egypt and the UAE secured Moscow's role a regional endorsement. Just like Abu Dhabi, Cairo, Riyadh, and Paris, Moscow chose to side with General Haftar, despite recognizing the UNbacked GNA in Tripoli. Since 2017, Russian support has centered on training, equipping and advising the LNA. ${ }^{49}$ The Russian role in Libya is spearheaded by the Wagner Group, which provides the Russian government with plausible deniability. By 2018, Moscow had deployed several hundred mercenaries to multiple training sites, airfields, forward bases and key energy and infrastructure sites to aid Haftar. ${ }^{50}$ However, the Russian role in Libya increased noticeably amid Haftar's offensive against Tripoli in April 2019 and surged in 2020. Rus- 
sia's deepening involvement in that period came as a result of the UAE's effort to rally support for Haftar after he failed several times to capture the capital and overthrow the GNA.

With Kremlin eager to expand its international footprint and pursue an activist foreign policy, Libya initially seemed like a promising venue. Moscow was happy to fill the vacuum left by the United States and its allies, to make common cause with Egypt and the Emirates, and to secure its own interests. The main reason why the Russian role surged in 2019-2020 is that it enjoys a low-cost, high-interest involvement mainly funded by the UAE in a way that enables Moscow to reap its fruits without big investments, high risks or having to officially admit it. Abu Dhabi equipped Haftar with Russia-made weapon systems, such as the Pantsir, funded the Russian role in Libya, paid-in collaboration with Saudi Arabia- the salaries of Russia's Wagner mercenaries and even facilitated an alliance between Haftar and the Assad regime in Syria to join forces and expedite the Russian transfer of Syrian mercenaries to Libya. ${ }^{51}$

According to an April 2020 UN report, ${ }^{52}$ since the beginning of 2000, Assad regime mercenaries have traveled from Damascus to Libya via at least 33 flights to support Haftar's offensive, alongside around 1,200 Russian Wagner mercenaries. ${ }^{53}$ Russian President Vladimir Putin has repeatedly denied any Russian intervention in Libya, but UN investigators have counted 339 Russian military flights to Libya between the November 1, 2019 and the July 31, 2020, mostly from Khmeimim airbase in Syria, with a potential volume of up to 17,200 tons of equipment. ${ }^{54}$

The American position is different. The Trump Administration has shown neither interest nor appetite to intervene in the North African country, given the bad experience of the Obama Administration and the death of U.S. Ambassador to Libya Christopher J. Stevens and U.S. Foreign Service Information Management Officer Sean Smith there in 2012. ${ }^{55}$ Officially, like the Obama Administration, the Trump Administration has recognized the UN-backed GNA in Tripoli. However, since MBZ, the de facto ruler of the UAE, has influence ${ }^{56}$ over Trump ${ }^{57}$ and his administration, ${ }^{58} \mathrm{Abu}$ Dhabi has managed to affect Trump's decisions from time to time, which has offered Abu Dhabi space to maneuver and continue supporting Haftar without triggering a U.S. reaction.

The Trump Administration has not criticized the UAE, despite its increase in arms supplies for Haftar since 2017. Moreover, in April 2020, Trump broke with the traditional official stance of recognizing the GNA and issued an official statement endorsing Haftar's campaign against Tripoli. ${ }^{59}$ The New York Times uncovered that Trump's endorsement of Haftar came one day after a phone conversation between the U.S. President and MBZ, after which Trump adjusted his position again. ${ }^{60}$ 
In September 2020, a confidential UN report that was presented to a UNSC panel detailed the secret, embargo-busting flights, mainly from the UAE and Russia, using flight data, shipping records and other tools

The Department of Defense, however, was worried about Russia's expanding military role in Tripoli and its repercussions ${ }^{61}$ for Africa, the Middle East, the EU and NATO's Southern flank. The Pentagon and the U.S. Africa Command (AFRICOM) ${ }^{62}$ in particular played a crucial role in exposing the depth of Russia's role in Libya and its aid to Haftar by releasing satellite images, relevant data and intel. ${ }^{63}$ For example, the Pentagon's Africa Command revealed in May 2020 the deployment of at least $14 \mathrm{MiG}-29 \mathrm{~s}$ and Su24 jets to Libya. The planes were flown from Russia to Hamadan base in $\operatorname{Iran}^{64}$ and from there to Syria, ${ }^{65}$ where their Russian markings were painted over to camouflage their origin. The aircraft were then flown into Libya ${ }^{66}$ Pentagon's worries allowed Turkey, a NATO ally, to play a bigger role in Libya while trying to support the GNA and contain Russia. This, however, didn't stop the UAE's quest to prop up Haftar, even while he was collapsing and falling back.

\section{The UAE's Final Push?}

After years of regional and international intervention in Libya, Turkey is the latest major power to arrive at the Libyan theatre. On November 27, 2019, the Turkish government and the GNA, the internationally recognized Libyan government, signed two separate MoUs -one on the maritime boundaries of countries in the Eastern Mediterranean and the other on military cooperation. The two parties have a common interest: on the one hand, these agreements prevented the fait accompli of isolating Ankara to a tiny maritime strip and undermined the collective effort by Greece, Greek Cyprus, Israel, and Egypt, backed by the UAE and Saudi Arabia, to sideline Turkey in the Eastern Mediterranean. On the other, the agreements qualified Libya to regain around $39,000 \mathrm{~km}^{2}$ of its Exclusive Economic Zone (EEZ) area that had been claimed by Athens. Greece had wanted to utilize Libya's hard circumstances to seize an area equal to almost four times the size of Lebanon. ${ }^{67}$

The military cooperation MoU enabled both parties to defend their rights and, most importantly, helped the UN-recognized GNA turn the tide of events in Libya to its fortune, especially starting from the second quarter of 2020. On January 12, 2020, the UN-recognized GNA announced a ceasefire in response to Turkish and Russian calls, as did the LNA. ${ }^{68}$ However, it turned out that Haftar's allies seized the moment to reorganize the LNA's ranks and resupply Haftar's forces with military equipment. On January 19, the German capital, 
As long as $\mathrm{MBZ}$ is in power in the UAE, no radical changes in $\mathrm{Abu}$ Dhabi's foreign policies should be expected
Russia, using flight data, shipping records and other tools. The report focused on the UAE in particular, among others, and stated that $\mathrm{Abu}$ Dhabi had sent at least 100 military cargo flights to Libya in the first half of 2020, many of them using three charter airlines registered in $\mathrm{Ka}$ zakhstan. The military cargo planes followed a disguise strategy that rested on turning off their transponders whenever they entered Egyptian or Libyan airspace. After being uncovered, Kazakhstan received several international complaints regarding the activity of the three implicated airplanes, prompting the Kazakh authorities to suspend their licenses. As a result, the Emirati military stepped in to fill the gap and shifted the reliance on cargo planes to its American-built C-17 Globemaster, thus sustaining the airbridge to Haftar and running 60 direct flights to Libya up to July $31 .^{72}$

Despite the Emirati's massive commitment to supporting the military dictator in Libya, Haftar does not appear to be salvaged. Many of his previous supporters, such as France and Egypt, may eventually drop him when they come to realize that he is obsolete as a military card. Haftar's demise became pretty obvious when both Fayez al Sarraj, the Prime Minister of Libya's UN-backed GNA, and Aguila Saleh, the speaker of the rival, Tobruk-based parliament in Eastern Libya, both agreed in August $2020^{73}$ to announce a ceasefire, resume talks and find a peaceful political solution to the crisis. Unsurprisingly, Haftar was not involved in these arrangements and that is why he rejected the ceasefire. ${ }^{74}$ To prevent him from sabotaging the agreement, warlord Haftar was incorporated in the process where he played a less important role compared to Aguila's through the $5+5$ joint military committee, which includes representatives of the GNA and the LNA. On October 24, 2020, the committee met in Geneva and reached a permanent ceasefire agreement in all areas of Libya.

\section{Conclusion}

The detailed account of the Emirati's destructive intervention in Libya given above shows how much Abu Dhabi is willing to invest in a military dictator/ regime to disrupt a peaceful resolution and ultimately prevent a democratic transition in Libya. With Turkey successfully thwarting Haftar's deadly offensive against Tripoli and the surrounding region where most of the Libyan population lives, and with Egypt scrambling to cut its losses by promoting Aguila Saleh as an alternative to Haftar, the UAE doesn't appear to be in a good position to continue executing its original plans for Libya. Despite this, it is unlikely that the UAE will give up easily on its goals there after years of impudent interference and meddling. Two factors suggest that Abu Dhabi will most probably continue 
seeking ways to call the shots in Libya. First, its ideologically driven agenda, which ignores the financial costs and political risks to the benefit of reaching the ultimate goals. Second, the fact that Libya's political future represents a makeor-break situation for Abu Dhabi's wider geopolitical ambitions will provide it with the needed motivation to continue its disruptive efforts there.

Abu Dhabi cannot afford the idea that Libya becomes an example of national reconciliation and peaceful power transition in the region as this will have direct impact on Libya's neighbors including Egypt, the ultimate spearhead of UAE since the 2013 military coup. Moreover, Abu Dhabi cannot tolerate political parties representing all walks of life participate in elections and reach to power because this undermines its narrative about radicalism and the need for a military dictator 'strong man' to rule. UAE's zero-sum game in Libya means that Abu Dhabi's failure to achieve its goals in the oil-rich North African country will pave the way to the rival camp (Turkey and Qatar) to exert greater influence both on geopolitical and geo-economic levels in Libya and beyond. Given that MBZ would not like to see this scenario happening any time soon in Libya if ever, it is safe to assume that Abu Dhabi will continue its meddling in Libya with or without Haftar.

Although Haftar wouldn't be able to do later what he already failed to do when he had the opportunity, the warlord may still be of use to Abu Dhabi. Knowing that the Libyan complications are far from resolved and judging from the Emirati's huge investment in supporting the Libyan warlord, Abu Dhabi will probably still want to use him as a spoiler of any particular future arrangements that would exclude it. Meanwhile, the Emiratis are exploring other options for post-wartime Libya. Aref al-Nayed, the former Libyan Ambassador to the UAE, is emerging fast as the UAE's coming man to replace Haftar. As long as MBZ is in power in the UAE, no radical changes in Abu Dhabi's foreign policies should be expected. However, whether the UAE will be able to act in Libya with full impunity in the next period as it has in the past, will largely depend on a set of variables that are not necessarily linked to it, such as the coming U.S. administration, its relations with the European powers and the nature of the Turkish role in Libya, among others.

\section{Endnotes}

1. David D. Kirkpatrick, "The Most Powerful Arab Ruler Isn't M.B.S. It's M.B.Z.," The New York Times, (June 2, 2019), retrieved from www.nytimes.com/2019/06/02/world/middleeast/crown-prince-mohammedbin-zayed.html.

2. Aram Roston, "A Middle East Monarchy Hired American Ex-Soldiers To Kill Its Political Enemies. This Could Be The Future of War," Bloomberg, (October 16, 2018), retrieved from www.buzzfeednews.com/ article/aramroston/mercenaries-assassination-us-yemen-uae-spear-golan-dahlan.

3. Saltanat Berdikeeva, "UAE Lures Foreign Mercenaries to Fight Proxy Wars," Inside Arabia, (February 18, 2020), retrieved from https://insidearabia.com/uae-lures-foreign-mercenaries-to-fight-proxy-wars/. 
4. "UAE Doing Too Little to Stem Money Laundering and Terrorist Finance: Watchdog," Reuters, (April 30, 2020), retrieved from www.reuters.com/article/us-emirates-financing-idUSKBN22B3CF.

5. "Sudanese Demand UAE Apology over Haftar Recruitment," Al Jazeera, (July 12, 2020), retrieved from www.aljazeera.com/news/2020/07/sudanese-demand-uae-apology-haftar-recruitment-2007141 75851614.htm.l.

6. Samuel Ramani, "Putin, Mohamed Bin Zayed Seek to Reclaim Common Ground On Libya," Al-Monitor, (July 15, 2020), retrieved from www.al-monitor.com/pulse/originals/2020/07/russia-uae-libya-policy-hifter-egypt.html.

7. Samer al-Atrush and David Wainer, "Western Team Went to Help Moscow's Man in Libya, UN Finds," Bloomberg, (March 14, 2020), retrieved from www.bloomberg.com/news/articles/2020-05-14/westernmercenaries-went-to-libya-to-help-moscow-s-man-un-finds.

8. "Mercenaries Channeled Funds Through Malta, UAE for Planned Libya Attack," Risk Screen, (May 26, 2020), retrieved from www.riskscreen.com/kyc360/news/investigators-identify-mercenaries-who-channeled-funds-through-malta-uae-for-planned-libya-attack/.

9. "UN Experts Probe Dispatch of Russian-Made Warplanes to Libya," The Financial Times, (May 21, 2020), retrieved from www.ft.com/content/ad6d1 bea-a1a4-4ca4-ae6f-253d2679bc5c.

10. Aidan Lewis, "Covert Emirati Support Gave East Libyan Air Power Key Boost-U.N. Report," Reuters, (June 9, 2017), retrieved from https://uk.reuters.com/article/uk-libya-security/covert-emirati-supportgave-east-libyan-air-power-key-boost-u-n-report-idUKKBN1902JQ.

11. Samer al-Atrush, "U.S. Arms Seized from Haftar's Forces, Libyan Officials Say," Bloomberg, (June 30, 2019), retrieved from www.bloomberg.com/news/articles/2019-06-30/libyan-officials-say-u-s-missilesseized-from-haftar-s-forces.

12. "Libya Demands Answers after French Missiles Found at Pro-Haftar Base," France 24, (July 12, 2019), retrieved from www.france24.com/en/20190712-libya-demands-answers-french-javelin-missilesfound-haftar-base.

13. "Libyan Fighters Seize U.S. and Chinese Missiles from Haftar's Forces," Reuters, (June 29, 2019), retrieved from www.reuters.com/article/us-libya-security/libyan-fighters-seize-u-s-and-chinese-missilesfrom-haftars-forces-idUSKCN1TU0W8.

14. "Addressing the Rise of Libya's Madkhali-Salafis," International Crisis Group, No. 200 (April 25, 2019), retrieved from www.crisisgroup.org/middle-east-north-africa/north-africa/libya/addressing-rise-libyas-madkhali-salafis.

15. Ali Bakeer, "The Iran-Haftar Links in Libya," (July 17, 2020), retrieved from https://warsawinstitute. org/iran-haftar-links-libya/.

16. "UAE Sets up Military Base in East Libya-HIS," Libya Observer, (October 28, 2016), retrieved from www.libyaobserver.ly/news/uae-sets-military-base-east-libya-ihs.

17. Lewis, "Covert Emirati Support Gave East Libyan Air Power Key Boost."

18. Metin Gürcan, "Turkey Untroubled by Conflict with Egypt, UAE in Libya," Al-Monitor, (July 27, 2020), retrieved from www.al-monitor.com/pulse/originals/2020/07/turkey-egypt-libya-large-scale-war-oversirte-jufra-unlikely.html.

19. "UAE Set to Open Military Base Near Libya 'to Support Haftar,"' The New Arab, (July 14, 2029), retrieved from https://english.alaraby.co.uk/english/news/2019/7/14/uae-set-to-open-pro-haftar-military-basenear-libya.

20. An Emirati airstrike killed 53 migrants in Tripoli in July 2019.

21. "Letter Dated 29 November 2019 From the Panel of Experts on Libya Established Pursuant to Resolution 1973 (2011) Addressed to the President of the Security Council," UNSC, (December 9, 2019), retrieved from www.securitycouncilreport.org/atf/cf/\%7B65BFCF9B-6D27-4E9C-8CD3CF6E4FF96FF9\%7D/S_2019_914.pdf, pp 1-374.

22. "UAE Implicated in Lethal Drone Strike In Libya," BBC, (August 28, 2020), retrieved from www.bbc. com/news/world-africa-53917791. 
23. Jared Malsin and Summer Said, "Saudi Arabia Promised Support to Libyan Warlord in Push to Seize Tripoli," The Wall Street Journal, (April 12, 2019), retrieved from www.wsj.com/articles/saudi-arabiapromised-support-to-libyan-warlord-in-push-to-seize-tripoli-11555077600.

24. Marie Jégo, Benoît Vitkine, and Frédéric Bobin, “En Libye, le Grand Marchandage Entre Moscou et Ankara," Le Monde, (January 24, 2020), retrieved from www.lemonde.fr/international/article/2020/01/24/ en-libye-le-grand-marchandage-entre-moscou-et-ankara_6027114_3210.html.

25. Samuel Ramani, "Saudi Arabia Steps Up Role in Libya," Al-Monitor, (February 24, 2020), retrieved from www.al-monitor.com/pulse/originals/2020/02/saudi-arabia-role-liyba-gna-hifter.html.

26. "Intel: Saudi Arabia Backs Egypt on Libya," Al-Monitor, (July 28, 2020), retrieved from www.al-monitor. com/pulse/originals/2020/07/intel-saudi-arabia-back-egypt-position-libya-hifter.html.

27. Paul Cochrane, "Saudi Arabia's Economic Crisis, Explained in 10 Graphics," Middle East Eye, (August 19, 2020), retrieved from www.middleeasteye.net/news/saudi-arabia-economic-crisis-oil-coronavirus-debt-vision-2030.

28. Ali Bakeer, "Sisi Won't Send His Army to Libya, but the UAE Demands Otherwise," TRT World, (June 23, 2020), retrieved from www.trtworld.com/opinion/sisi-won-t-send-his-army-to-libya-but-the-uaedemands-otherwise-37512.

29. "5 Charts that Reveal the State of the Global Arms Trade," World Economic Forum, (March 14, 2019), retrieved from www.weforum.org/agenda/2019/03/5-charts-that-reveal-the-state-of-the-global-armstrade/.

30. Bakeer, "Sisi Won't Send His Army to Libya, but the UAE Demands Otherwise."

31. Ali Bakeer, "The Turkey-Libya Agreement Benefits Egypt, But the UAE Is a Spoiler," (June 15, 2020), retrieved from www.trtworld.com/opinion/the-turkey-libya-agreement-benefits-egypt-but-the-uae-isa-spoiler-37292.

32. "An Emirati Academic Threatens to Send the Egyptian Army to Fight In Libya," Mubasher Al Jazeera,

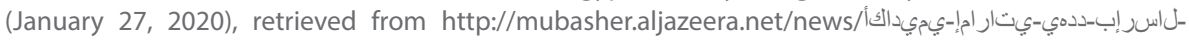

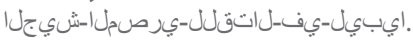

33. Abdulkhaleq Abdulla, Twitter, 08:40 PM, (June 6, 2020), retrieved from https://twitter.com/Abdulkhaleq_UAE/status/1269323336536002560?s=20.

34. Bakeer, "Sisi Won't Send His Army to Libya, but the UAE Demands Otherwise."

35. "Western Arms Exports Fuel Conflict in the Middle East, North Africa," DW, (September 24, 2020), retrieved from www.dw.com/en/us-european-weapons-exports-middle-east-north-africa/a-55039271.

36. Ola Salem and Hassan Hassan, "Arab Regimes Are the World's Most Powerful Islamophobes," Foreign Policy, (March 29, 2019), retrieved from https://foreignpolicy.com/2019/03/29/arab-regimes-are-theworlds-most-powerful-islamophobes/.

37. Jacques Neriah, "France's Military Presence in Libya? 'Un Secret de Polichinelle,' As the French Say," Jerusalem Center for Public Affairs, (May 7, 2019), retrieved from https://jcpa.org/frances-military-presence-in-libya-un-secret-de-polichinelle-as-the-french-say/.

38. Jacques Neriah, "France's Military Presence in Libya? 'Un Secret de Polichinelle,' As the French Say”.

39. Chris Stephen, "Three French Special Forces Soldiers Die in Libya," The Guardian, (July 20, 2016), retrieved from www.theguardian.com/world/2016/jul/20/three-french-special-forces-soldiers-die-in-libya-helicopter-crash.

40. "Men with French Passports Crossing from Libya Are Linked to Haftar: Tunisian Source," Middle East Eye, (April 23, 2019), retrieved from https://www.middleeasteye.net/news/men-french-passports-crossing-libya-are-linked-haftar-tunisian-source.

41. "Missiles Found at Base of Libyan Warlord Are Ours, France Admits," The Guardian, (July 10, 2019), retrieved from www.theguardian.com/world/2019/jul/10/missiles-found-at-base-of-libyan-warlord-areours-france-admits\#: :text=France\%20has\%20said\%20some\%20of,its\%20role\%20in\%20the\%20conflict.

42. Ali Bakeer, Twitter, 08:37 AM, (December 25, 2019), retrieved from https://twitter.com/AliBakeer/status/1209709762570596352?s=20. 
43. "GNA: Europe's IRINI Mission In Haftar's Favor," Asharq al-Awsat, (May 23, 2020), retrieved from https:// english.aawsat.com/home/article/2298301/gna-europe's-irini-mission-haftar's-favor.

44. Emadeddin Badi, "Russia Isn't the Only One Getting Its Hands Dirty in Libya," Foreign Policy, (April 21, 2020), retrieved from https://foreignpolicy.com/2020/04/21/libyan-civil-war-france-uae-khalifa-haftar/.

45. David Ehl, “EU, France Split on Libya as Khalifa Haftar Strikes Tripoli,” DW, (April 23, 2019), retrieved from www.dw.com/en/eu-france-split-on-libya-as-khalifa-haftar-strikes-tripoli/a-48449352.

46. "Libyan PM Accuses France of Supporting 'Dictator' Haftar," France 24, (April 24, 2019), retrieved from www.france24.com/en/20190424-libyan-pm-accuses-france-supporting-dictator-haftar.

47. "Minister Jean-Yves Le Drian: France Is in Libya to Combat Terrorism," Ministry of Europe and Foreign Affairs, (May 2, 2019), retrieved from www.diplomatie.gouv.fr/en/our-ministers/jean-yves-le-drian/ press/article/minister-jean-yves-le-drian-france-is-in-libya-to-combat-terrorism-02-05-19.

48. Jean-Yves Le Drian , "Nous Attendons des Clarifications avec la Turquie," Public Senat, (July 9, 2020), retrieved from www.publicsenat.fr/article/parlementaire/jean-yves-le-drian-nous-attendons-des-clarifications-avec-la-turquie-183774.

49. Brian Katz and Joseph S. Bermudez Jr., "Moscow's Next Front: Russia's Expanding Military Footprint in Libya," (June 17, 2020), retrieved from www.csis.org/analysis/moscows-next-front-russias-expanding-military-footprint-libya.

50. Sergey Sukhankin, "Continuation of Policy by Other Means: Russian Private Military Contractors in the Libyan Civil War," The Jamestown Foundation,( February 7, 2020), retrieved from https://jamestown. org/program/continuation-of-policy-by-other-means-russian-private-military-contractors-in-the-libyan-civil-war/.

51. Bakeer, "The Iran-Haftar Links in Libya."

52. "Russian Mercenaries Are Fighting in Libya, UN Diplomats Confirm," The Moscow Times, (May 7, 2020), retrieved from www.themoscowtimes.com/2020/05/07/russian-mercenaries-are-fighting-in-libya-un-diplomats-confirm-a70204.

53. Bakeer, "The Iran-Haftar Links in Libya."

54. Declan Walsh, "Waves of Russian and Emirati Flights Fuel Libyan War, U.N. Finds," The New York Times, (September 3, 2020), retrieved from www.nytimes.com/2020/09/03/world/middleeast/libya-russia-emirates-mercenaries.html.

55. "Libya Attack Brings Challenges for U.S.," The New York Times, (September 12, 2012), retrieved from www.nytimes.com/2012/09/13/world/middleeast/us-envoy-to-libya-is-reported-killed.html.

56. "UAE's Prince Mohammed Bin Zayed's Growing Influence on the U.S.," NPR, (June 6, 2019), retrieved from www.npr.org/2019/06/06/730339596/uaes-prince-mohammed-bin-zayed-s-growing-influenceon-the-u-s.

57. "Report: UAE Linked to Illegal Influence in 2016 US Election," Al Jazeera, (December 6, 2019), retrieved from www.aljazeera.com/news/2019/12/06/report-uae-linked-to-illegal-influence-in-2016-uselection/.

58. Kate Kizer, "The UAE's Dominant Role in Trump-Era Foreign Policy," The American Prospect, (August 2, 2019), retrieved from https://prospect.org/world/uae-s-dominant-role-trump-era-foreign-policy/.

59. Guido Steinberg, "Regional Power United Arab Emirates," SWP, (July 10, 2020), retrieved from www. swp-berlin.org/10.18449/2020RP10/, p. 23.

60. Kirkpatrick, "The Most Powerful Arab Ruler Isn't M.B.S. It's M.B.Z."

61. "Russia Raises Stakes with 'Brazen' Military Intervention in Libyan Conflict," CNN, (June 9, 2020), retrieved from https://edition.cnn.com/2020/06/09/world/russia-libya-military-intervention-intl/index. html.

62. "New Evidence of Russian Aircraft Active in Libyan Airspace," U.S. Africa Command Public Affairs, (June 18, 2020), retrieved from www.africom.mil/pressrelease/32941/new-evidence-of-russian-aircraftactive-in-li. 
63. Katz and Bermudez Jr., "Moscow's Next Front."

64. Bakeer, "The Iran-Haftar Links in Libya."

65. Tyler Rogoway, "MiG-29 Fighters Were at Russia's Air Base in Syria Just Before Showing Up in Libya," The Drive, (May 26, 2020), retrieved from www.thedrive.com/the-war-zone/33666/mig-29-fighterswere-at-russias-air-base-in-syria-just-before-showing-up-in-libya.

66. Eric Schmitt, "Russian Attack Jets Back Mercenaries Fighting in Libya," The New York Times, (September 11, 2020), retrieved from www.nytimes.com/2020/09/11/us/politics/russian-jets-mercenaries-libya. html.

67. Ali Bakeer, "Turkish-Libyan Alliance in Eastern Mediterranean: A Game Changer?," The New Arab, (December 10, 2019), retrieved from https://english.alaraby.co.uk/english/indepth/2019/12/10/turkish-libyan-alliance-in-eastern-mediterranean-a-game-changer.

68. "Libya: The Government of National Accord Announces a Ceasefire Hours after a Similar Announcement by Haftar's Forces," France 24, (January 12, 2020), retrieved from www.france24.com/ar/20200112-

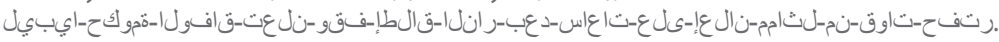

69. "Sheikh Mohamed Bin Zayed Meets Angela Merkel in Berlin," The National, (January 18, 2020), retrieved from www.thenational.ae/world/sheikh-mohamed-bin-zayed-meets-angela-merkel-in-berlin$1.966041 \# 1$.

70. "Abu Dhabi Boosts Deliveries to Khalifa Haftar," Africa Intelligence, (January 30, 2020), retrieved from www.africaintelligence.com/north-africa_politics/2020/01/30/abu-dhabi-boosts-deliveries-to-khalifahaftar,108391623-art.

71. Walid Abdullah, "UAE Sent 100 Arms Shipments to Haftar: Libya Gov't," Anadolu Agency, (February 24, 2020), retrieved from www.aa.com.tr/en/middle-east/uae-sent-100-arms-shipments-to-haftar-libya-govt/1743365.

72. Walsh, "Waves of Russian and Emirati Flights Fuel Libyan War."

73. "Statement by United Nations Support Mission in Libya," UNSMIL, (August 21, 2020), retrieved from https://unsmil.unmissions.org/acting-srsg-williams-warmly-welcomes-points-agreement-today\%E2\% 80\%99s-declarations-pm-serraj-and-speaker.

74. "Libya: Warlord Haftar Not on Board with Ceasefire, Wants War to Continue," The North Africa Journal, (August 24, 2020), retrieved from north-africa.com/2020/08/libya-warlord-haftar-not-on-board-withceasefire-wants-war-to-continue/. 


\section{SETA}

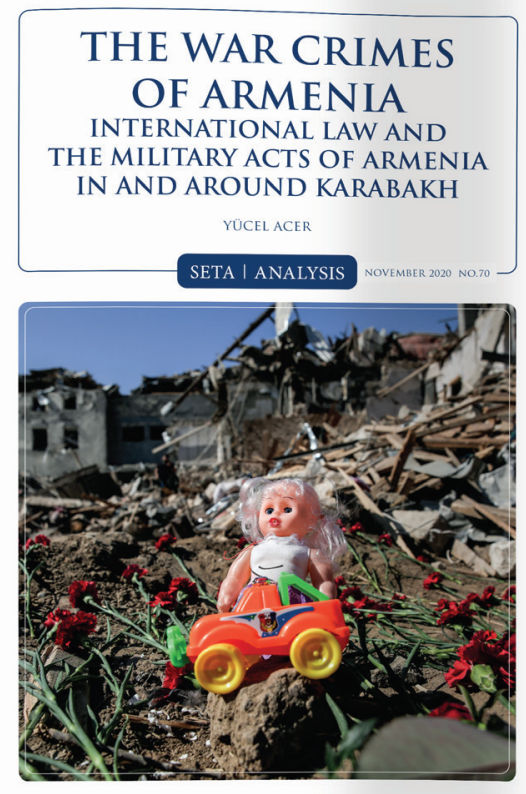

OF ARMENIA

INTERNATIONAL LAW AND THE MILITARY ACTS OF ARMENIA

.

\section{LNG Trade | A Silver Lining in U.S.-Turkey Bilateral Relations \\ Gloria Shkurti Özdemir}

This analysis argues that the increase in the LNG trade between Turkey and the U.S. is a win-win situation for both states.

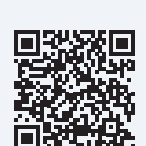

The War Crimes of Armenia International Law and The Military Acts of Armenia in and Around Karabakh

Yücel Acer

This analysis discusses the violations of international humanitarian laws committed by Armenia since September 27, 2020 in the occupied Azerbaijani lands.

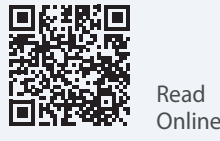

\section{LNG TRADE}

A SILVER LINING IN U.S.-TURKEY BILATERAL RELATIONS

LORIA SHKURTI ÖZDEMIR

SETA I ANALYSIS

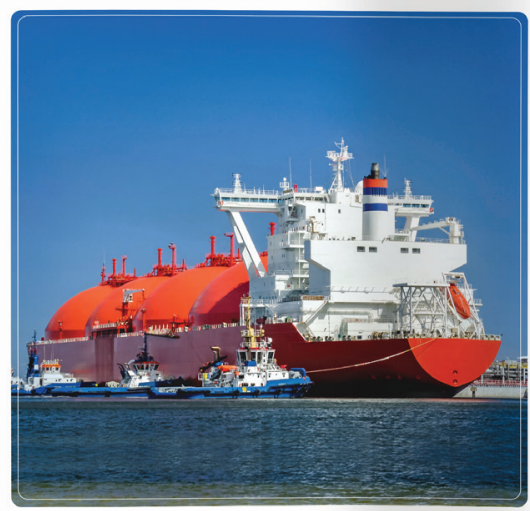

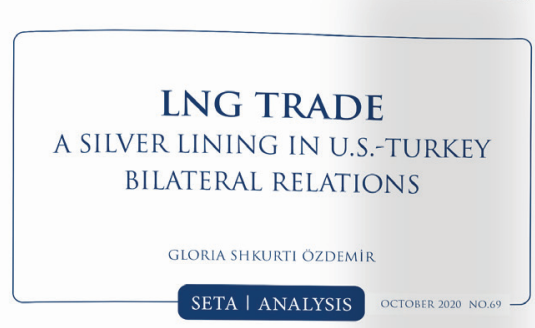

